\title{
PENGGUNAAN ANTIBIOTIK RESTRIKSI PADA PASIEN GEA, ISK DAN DEMAM TIFOID DI BANGSAL PENYAKIT DALAM RSUD H. ABDUL MANAP KOTA JAMBI PERIODE 2017-2019
}

\section{THE USE OF RESTRICTION ANTIBIOTICS IN GEA, ISK AND TYPHOID FEVER PATIENTS IN THE INTERNAL MEDICINE WARD OF RSUD H. ABDUL MANAP HOSPITAL, JAMBI CITY FOR THE PERIOD OF 2017-} 2019

\author{
Bunga Debi Lestari ${ }^{1 *}$, Yuni andriani ${ }^{2}$, Rahmadevi ${ }^{3}$ \\ Program Studi Farmasi, STIKES Harapan Ibu Jambi ${ }^{1}$ \\ Program Studi Farmasi, STIKES Harapan Ibu Jambi² \\ Program Studi Farmasi, STIKES Harapan Ibu Jambi ${ }^{3}$ \\ ${ }^{1}$ bungadebi110398@gmail.com ${ }^{2}$ yuni23_fmasi@yahoo.com ${ }^{3}$ zuldev1807@gmail.com
}

\begin{abstract}
ABSTRAK
Tingginya penggunaan antibiotik dapat menyebabkan tingginya kejadian resistensi antibiotik. Semua pihak yang berkaitan melakukan berbagai upaya untuk mengatasi masalah tersebut salah satunya dengan antibiotik restriksi atau pembatasan jenis antibiotik. Penelitian ini bertujuan untuk Mengetahui Persentase Penggunaan antibiotik restriksi pada pasien GEA, ISK dan demam tifoid di bangsal penyakit dalam RSUD H. Abdul Manap Kota Jambi periode 2017-2019. Penelitian ini merupakan penelitian deskriptif dengan pengambilan data secara retrospektif yang didasarkan pada data rekam medik dan diperoleh 47 pasien yang sesui dengan kriteria inklusi. Dari hasil penelitian penggunaan antibiotik restriksi lebih banyak ditemukan pasien perempuan dari pada laki-laki serta pada kategori usia remaja akhir ( 17-25 tahun ). Jenis antibiotik restriksi yang digunakan di bangsal penyakit dalam RSUD H. Abdul Manap Kota Jambi periode 2017-2019 adalah ciprofloxacin 20\%, levofloxacin $8 \%$ dan meropenem 1\%. Presentase penggunaan antibiotik restriksi periode 2017-2019 pada diagnosis GEA mengalami peningkatan pada tahun 2017 sebesar 22\% dan meningkat menjadi 44\% ditahun 2018 dan 2019. Pada diagnosis ISK mengalami penurunan dan peningkatan, yaitu ditahun 2017 sebesar 16\%, mengalami peningkatanan menjadi 43\% ditahun 2018. Kemudian ditahun 2019 menurun kembali menjadi 29\%. Pada diagnosis demam tifoid mengalami penurunan dan peninkatan yaitu pada tahun 2017 sebesar 19\%, mengalami penurunan sebesar 12\% ditahun 2018 . Kemudian ditahun 2019 meningkat menjadi 25\%. Kesimpulan yang didapat pada penelitian ini adalah Presentase penggunaan antibiotik restriksi periode 2017-2019 Pada diagnosis GEA sebesar 22\%, 44\%, dan 44\%. Pada diagnosis ISK sebesar 16\%, 43\%, dan 29\%. Pada diagnosis demam tifoid sebesar $19 \%, 12 \%$, dan $25 \%$.
\end{abstract}

Kata Kunci : Antibiotik Restriksi, Demam Tifoid, ISK, GEA, Resistensi.

\section{ABSTRACT}

The high use of antibiotics can cause a high incidence of antibiotic resistance. All parties concerned have made various efforts to overcome the problem, one of which is by antibiotic restriction 
Journal of Healthcare Technology and Medicine Vol. 6 No. 2 Oktober 2020

Universitas Ubudiyah Indonesia

e-ISSN : 2615-109X

or antibiotic type restrictions. This study aims to determine the percentage of the use of restriction antibiotics in GEA, ISK and typhoid fever patients in the ward ward in H. Abdul Manap Hospital Jambi City period 2017-2019. This research is a descriptive study with retrospective data collection based on medical record data and obtained 47 patients who were in accordance with the inclusion criteria. From the results of the study the use of antibiotics restriction found more female patients than men and in the late adolescent age category (17-25 years). The type of restriction antibiotics used in the ward of the disease in H. Abdul Manap Regional Hospital in Jambi City for the period of 2017-2019 are ciprofloxacin 20\%, levofloxacin $8 \%$ and meropenem 1\%. The percentage of restriction antibiotic use for the 2017-2019 period in the diagnosis of GEA increased in 2017 by 22\% and increased to 44\% in 2018 and 2019. In the diagnosis of ISK decreased and increased, namely in 2017 by $16 \%$, increased to $43 \%$ in the year 2018. Then in 2019 it will decrease again to $29 \%$. In the diagnosis of typhoid fever decreased and increased in 2017 by 19\%, decreased by 12\% in 2018. Then in 2019 it increased to 25\%. The conclusions obtained in this study were the percentage of restriction antibiotic use for the period of 2017-2019 at the diagnosis of GEA by 22\%, 44\%, and 44\%. At diagnosis of ISK by 16\%, 43\%, and 29\%. At the diagnosis of typhoid fever by 19\%, 12\%, and $25 \%$.

Keywords : Restriction antibiotic, Resistance, GEA, ISK, Typhoid Fever

\section{PENDAHULUAN}

Menurut (Arifi dkk, 2015) Resistensi antibiotik merupakan masalah dunia di Negara berkembang dan Negara maju. Resistensi antibiotik disebabkan oleh faktor terbesar yaitu tingginya penggunaan antibiotik. Tingginya penggunaan antibiotik akan meningkatkan resiko penggunaan antibiotik yang tidak rasional, angka mortalitas, biaya, kejadian efek samping obat dan resistensi antibiotik (Pratama, 2019). Antibiotik restriksi atau pembatasan jenis antibiotik atau kelas antibiotik dalam formularium rumah sakit telah diakui sebagai salah satu strategi untuk mengurangi kejadian resistensi antibiotik, menekan biaya antibiotik, serta menurunkan pemakaian berlebihan antibiotik spektrum luas secara empiris (Fauzia, 2015)

Menurut hasil penelitian Prevalensi Kuman Multi Drug Resistance (MDR) di RSUP Dr.M.Djamil padang periode 2010-2012 ditemukan resistensi antibiotik tertinggi pada tahun 2010 (62\%) kemudian menurun ditahun 2011 (55\%) dan terjadi kembali peningkatan di tahun 2012 (58\%) (Sjahjadi dkk, 2014). Sedangkan hasil penelitian di RSUP Dr.Soeradji Tirtinegoro klaten prevalensi resistensi antibiotik terus meningkat dari tahun 2015-2018 yaitu 7,69 \%, 5,63\%, 10,85\%, dan 12,49\% (Nuryah dkk, 2019). Kemudian hasil penelitian selanjutnya menunjukan prevalensi resistensi antibiotik di RSUD Dr.Saiful Anwal malang ada terjadinya penurunan, dimana pada tahun 2010 yaitu 41,8 \% kemudian di tahun 2011 yaitu 41,7 \%. Sedangkan di tahun 2012 didapatkan prevalensi resistensi antibiotik tertinggi yaitu 45,3\% dan prevalensi terendah ditemukan pada tahun 2013 yaitu 33,5 \% (Erikawati dkk, 2016). Data pada tahun 2009, Indonesia memasuki peringkat ke 8 dari 27 negara dengan predikat multidrug-resisten tertinggi di dunia (Estiningsih dkk, 2016). Diperkirakan pada tahun 2050, setidaknya 10 juta jiwa per tahun akan berisiko mengalami resistensi antibiotik (Bryce et al 2018). Menurut (Desrini, 2015) Berdasarkan AMRIN Study (Antimicrobial Resistance in Indonesia, Prevalence and Prevention) hasil penelitian Indonesia dan Belanda di RSUD Dr. Soetomo Surabaya dan RSUP Dr. Kariadi 
Journal of Healthcare Technology and Medicine Vol. 6 No. 2 Oktober 2020

Universitas Ubudiyah Indonesia

e-ISSN : 2615-109X

Semarang di tahun 2001-2005 terdapatnya bakteri multi-resisten, seperti MRSA (Methicillin Resistant Staphylococcus aureus) dan bakteri penghasil ESBL (Extended Spectrum Beta Lactamases).

Penyebab utama yang mendukung terjadinya resistensi antibiotik yaitu penggunaan yang kurang tepat (irrasional), lemahnya pengawasan yang dilakukan pemerintah dalam distribusi dan pemakaian antibiotik (Utami, 2011). Dari hasil penelitian di atas presentase kejadian resistensi antibiotik masih tergolong tinggi. Maka dari itu peneliti tertarik untuk membahas tentang penelitian ini. Peneliti ingin mengetahui presentase penggunaan antibiotik restriksi di rumah sakit terutama di Provinsi Jambi.

\section{METODE PENELITIAN}

Penelitian ini merupakan penelitian non-eksperimental yang bersifat deskriptif yang berarti mendeskripsikan atau menggambarkan data yang telah terkumpul dan tidak ada analisis yang spesifik untuk pengolahan data, sehingga hasilnya berupa perhitungan presentase dari Penggunaan Antibiotik Restriksi di Bangsal Penyakit Dalam RSUD H. Abdul Manap Kota Jambi periode 2017-2019 dengan pengambilan data secara retrospektif yaitu pengamatan terhadap peristiwa-peristiwa yang telah terjadi pada data rekam medik.

\section{HASIL DAN PEMBAHASA}

Penelitian dilakukan pada bulan juni 2020 di RSUD H.Abdul Manap Kota Jambi. Berdasarkan hasil penelitian yang diperoleh dari rekam medis pasien penyakit dalam (GEA,ISK dan Demam Tifoid) dari tahun 2017-2019 data yang didapat berdasarkan inklusi sebanyak 47 pasien.

\section{Karakteristik pasien}

Tabel 1. Karakteristik Pasien yang Menggunakan Antibiotik Restriksi Berdasarkan Jenis Kelamin

\begin{tabular}{|c|c|c|c|}
\hline \multirow{2}{*}{ No } & \multirow{2}{*}{ Diagnosa } & \multicolumn{2}{|c|}{ Jenis kelamin } \\
\cline { 3 - 4 } & & Laki-laki & Perempuan \\
\hline 1. & GEA & 8 & 14 \\
\hline 2. & ISK & 7 & 8 \\
\hline 3. & Demam Tifoid & 7 & 3 \\
\hline & Total & $\mathbf{2 2}$ & $\mathbf{2 5}$ \\
\hline
\end{tabular}

Keterangan : GEA = gastroenteritis

$$
\text { ISK = Infeksi Saluran Kemih }
$$

Berdasarkan jenis kelamin diketahui hasil penelitian penggunaan antibiotik restriksi dari tahun 2017-2019 pada penyakit GEA, ISK dan Demam Tifoid lebih banyak ditemukan adalah pasien perempuan dari pada laki-laki 
Journal of Healthcare Technology and Medicine Vol. 6 No. 2 Oktober 2020

Universitas Ubudiyah Indonesia

e-ISSN : 2615-109X

Tabel 2. Karakteristik Pasien yang Menggunakan Antibiotik Restriksi Berdasarkan Usia

\begin{tabular}{ccccc}
\hline \multirow{2}{*}{ No } & \multirow{2}{*}{ Usia } & \multicolumn{3}{c}{ Diagnosa } \\
\cline { 3 - 5 } & & GEA & ISK & Demam typhoid \\
\hline 1. & Remaja awal (12-16 tahun) & 0 & 0 & 0 \\
\hline 2. & Remaja akhir (17-25 tahun) & 11 & 2 & 6 \\
\hline 3. & Dewasa awal (26-35 tahun) & 5 & 1 & 1 \\
\hline 4. & Dewasa akhir (36-45 tahun) & 4 & 6 & 3 \\
\hline 5. & Lansia awal (46-55 tahun) & 2 & 4 & 0 \\
\hline 6. & Lansia akhir (56-65 tahun) & 0 & 2 & 0 \\
\hline 7 & Manula (65 tahun keatas) & 0 & 0 & 0 \\
\hline
\end{tabular}

Berdasarkan usia diketahui hasil penelitian penggunaan antibiotik restriksi dari tahun 2017-2019 pada penyakit GEA,ISK dan Demam tifoid lebih banyak ditemukan pada usia remaja akhir (17-25) tahun.

\section{Presentase pasien yang menggunakan antibiotic restriksi berdasarkan penyakit.}

Dari hasil gambar 1 penyakit GEA adalah penyakit yang paling banyak menggunakan antibiotik restriksi yaitu 22 pasien Pada penyakit ISK didapatkan 15 pasien yang menggunakan antibiotik restriksi dan pada penyakit Demam Tifoid didapatkan 10 pasien yang menggunakan antibiotik restriksi.

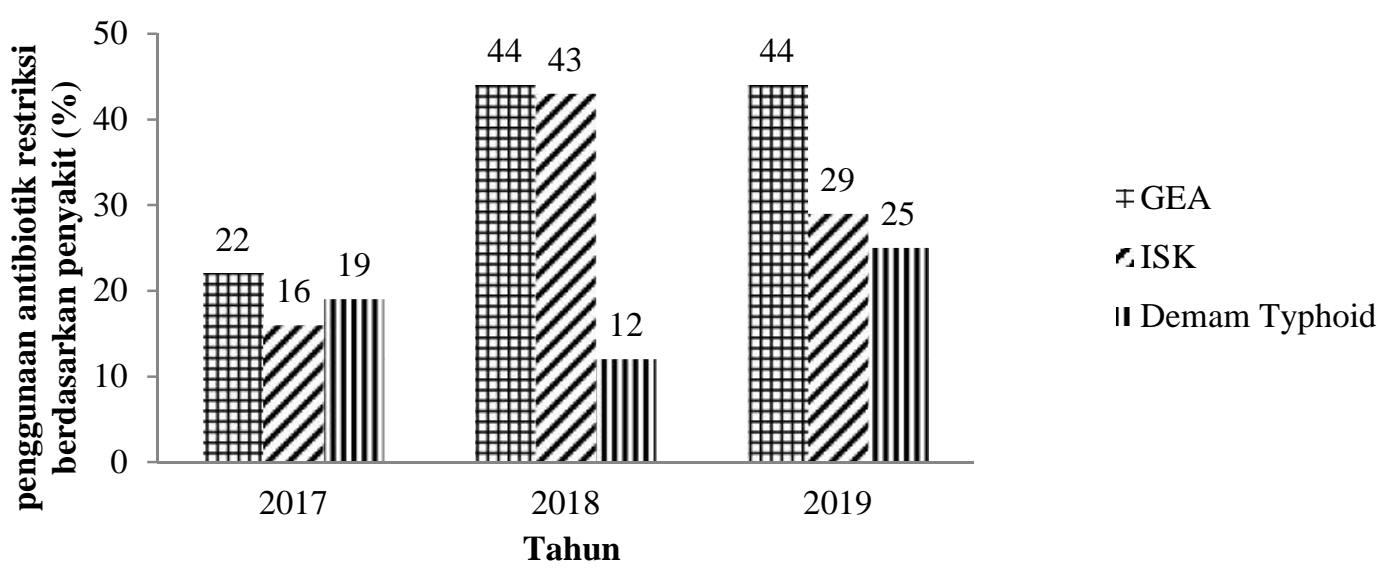

Gambar 1. Grafik presentase penggunaan antibiotik restriksi berdasarkan penyakit Periode 2017-2019.

\section{Presentase antibiotik restriksi yang digunakan}




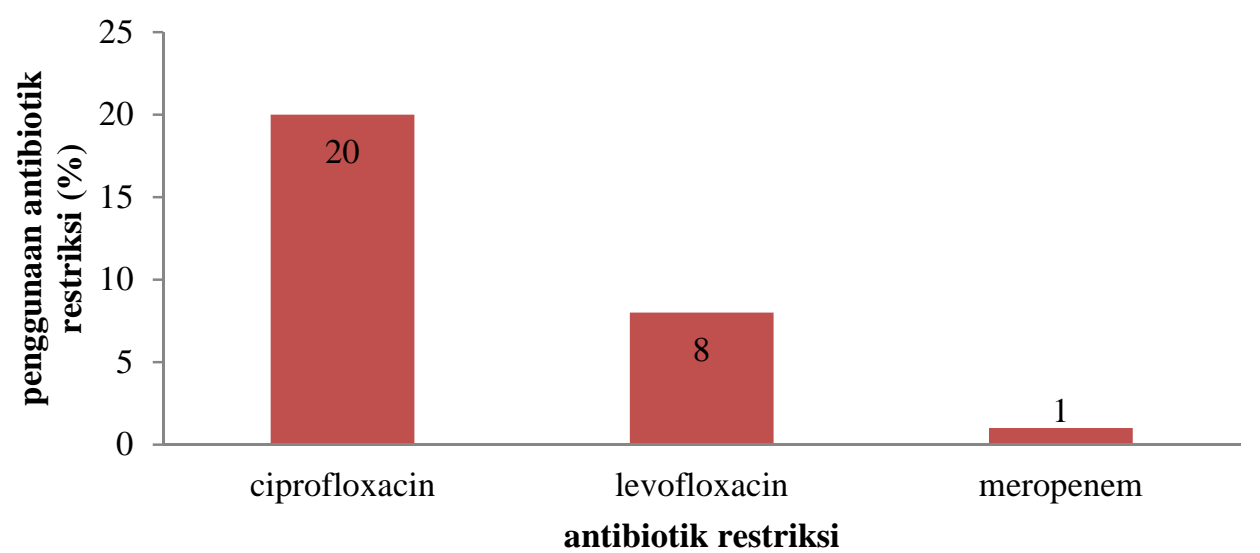

Gambar 2. Grafik Persentase Antibiotik Restriksi yang Digunakan periode 2017-2019

\section{Karakteristik Pasien}

Dalam periode 2017-2019 dari 3 penyakit di Bangsal Penyakit Dalam pasien yang menggunakan Antibiotik Restriksi berdasarkan jenis kelamin didapatkan jumlah pasien Perempuan lebih banyak dibandingkan pasien laki-laki. Pada pasien penyakit GEA pasien perempuan lebih banyak dibandingkan lakilaki karena perempuan lebih banyak terlibat dalam kegiatan rumah tangga. Kegiatan sehari hari dalam rumah tangga dapat berpengaruh terhadap kejadian GEA seperti memasak, membersihkan rumah dari debu dan tugas lainnya yang menjadi sumber paparan patogen dalam rumah tangga serta berbagai bahan kimia (Hidayanti, 2012). Berdasarkan hasil penelitian, pada tabel 2 yang menjabarkan usia pasien GEA didapatkan hasil bahwa penyakit GEA lebih sering terjadi sekelompok usia remaja akhir (17-25). Berbeda dengan penelitian komrompis et al menyatakan pasien terbanyak pada usia 41-50 tahun hal ini disebabkan oleh penurunan sistem imun dan fungsi organ.(Korompis et al., 2013).

Kemudian dari hasil penelitian dapat diketahui persentase kejadian pada pasien ISK yang tercantum pada tabel 1 berdasarkan jenis kelamin pada pasien ISK yang menggunakan antibiotik restriksi didapatkan jumlah pasien perempuan lebih banyak dibandingkan laki-laki. Penelitian ini sesuai dengan pendapat (Herlina dkk, 2015) dimana jenis laki-laki sebesar 34,4 \% sedangkan perempuan lebih banyak sebesar 65,6\%. Penelitian (Kendari, 2018) juga menunjukkan pasien yang menderita ISK didominasi jenis kelamin perempuan sebanyak 24 pasien sedangkan laki-laki sebanyak 10 pasien. Hal ini dikarenakan faktor anatomis, efek hormonal dan pola reilaku. Infeksi saluran kemih banyak terjadi pafa wanita karena alat genital perempuan yang memiliki uretra lebih pendek sehingga bakteri kontaminan lebih mudah memperoleh akses ke kandung kemih (Savitri dkk, 2017). Berdasarkan hasil penelitian, pada tabel 2 yang menjabarkan usia pasien ISK didapatkan hasil bahwa penyakit ISK lebih sering terjadi sekelompok usia dengan rentan 36 sampai 45 tahun yang termasuk kategori dewasa akhir. penelitian ini sesuai dengan (Kendari, 2018) menunjukkan angka kejadian terbanyak 
Journal of Healthcare Technology and Medicine Vol. 6 No. 2 Oktober 2020

Universitas Ubudiyah Indonesia

e-ISSN : 2615-109X

pada kelompok umur 36-35 tahun sebanyak 10 pasien. Hasil penelitian menunjukan infeksi saluran kemih banyak terjadi pada usia dewasa, dimana wanita sudah mulai melakukan aktivitas seksual pada usia tersebut dan adanya penyakit kronis, gangguan fungsiobal genitourinaria dan penggunaan obat-obat tertentu. (Savitri et al., 2017)

Pada penyakit Demam Tifoid berdasarkan dari hasil penelitian dapat diketahui presentase kejadian pada pasien Demam Tifoid penggunaan antibiotik restriksi didapatkan jumlah pasien laki-laki lebih tinggi dibandingkan pasien perempuan, hasil ini sama seperti penelitian (Nuruzzaman, 2016) dalam penelitian menyatakan bahwa yang terdiagnosa menderita demam tifoid lebih banyak terjadi pada jenis kelamin laki-laki dibandingkan dengan jenis kelamin perempuan. Secara umum setiap penyakit dapat menyerang siapa saja baik laki-laki maupun perempuan. Departemen kesehatan repunlik Indonesia (2009) menyatakan bahwa laporan hasil riset kesehatan dasar demam tifoid terutama ditemukan lebih banyak diderita pada laki-laki dibandingkan perempuan. Hasil penelitian ini diperkuat dengan penelitian (Pramitasari, 2013) yang menyatakan bahwa lakilaki memiliki resiko menderita demam tifoid dibandingkan dengan perempuan dikarenakan laki-laki lebih banyak beraktifitas diluar rumah sehingga mengkonsumsi makanan siap saji atau makanan warung yang biasanya banyak mengandung penyedap rasa dan kebersihan yang belum terjamin, dibandingkan perempuan lebih menyukai masakan dari rumah dari pada masakan diluar rumah hingga perempuan lebih memperhatikan kebersihan makanan yang dikonsumsi. Kebiasaan ini menyebabkan laki-laki ditularkan melalui makanan seperti demam tifoid (Astuti, 2010). Berdasarkan hasil penelitian yang tercantum pada tabel 2 menunjukkan bahwa penyakit demam tifoid yang terjadi di RSUD H. abdul manap jambi paling banyak terjadi pada usia 17 sampai 25 tahun dengan jumlah 5 pasien. Hal ini didukung oleh (Rakhman, 2009) menyatakan semakin bertambahnaya usia diyakini makin banyak terpapar berbagai macam penyakit menular dan imunitas akan semakin turun dikarenakan usia yang teris bertambah maka juga diyakini adanya perbedan pola hidup dan aktivitas yang dilakukan. Diasumsikan bawa sistem imun pada usia dibawah 25 tahun belum sempurna, sanitasi yang buruk serta jajan diluar yang kurang terjamin kebersihannya dapat menyebabkan penyakit demam tifoid (Melarosa dkk, 2019).

\section{Presentase penggunaan antibiotik restriksi berdasarkan penyakit}

Dari hasil gambar 1 Persentasi penggunaan antibiotik restriksi pada diagnosis GEA dalam 3 tahun terakhir pengalami peningkatan dan penetapan yaitu $22 \%, 44 \%$ dan $44 \%$. Persentase penggunaan antibiotik restriksi pada diagnosis ISK dalam 3 tahun mengalami peningkatan di tahun 2018 yaitu dengan persentasi 16\%, 43\%\% dan $29 \% \%$, sedangkan penggunaan antibiotik restriksi pada diagnosis Demam Tifoid dalam 3 tahun mengalami penurunan di tahun 2018 kemudian naik kembali di tahun 2019 dengan presentasi 19\%, 12\% dan $25 \%$. Penurunan presentasi terjadi karena penggunaan antibiotik yang sudah rasional sedangkan peningkatan presentasi terjadi karena penggunaan antibiotik yang irasional sehingga menyebabkan resistensi antibiotik. 
Journal of Healthcare Technology and Medicine Vol. 6 No. 2 Oktober 2020

Universitas Ubudiyah Indonesia

e-ISSN : 2615-109X

Resistensi antibiotik menimbulkan infeksi mikroorganisme yang tidak dapat diobati dengan antibiotik biasa yang mengakibatkan perlunya penggunaan antibiotik jenis baru dengan spektrum lebih luas. Maka dari itu pasien yang telah mengalami resistensi antibiotik menggunakan antibiotik restriksi (Negara, 2014).

\section{Jenis Antibiotik Restriksi yang Digunakan}

Antibiotik Restriksi pada penelitian ini diketahui berdasarkan panduan formularium nasional dan formularium rumah sakit $\mathrm{H}$. Abdul Manap yang didapatkan dari ruang instalasi farmasi RSUD H. Abdul Manap Kota Jambi. Penggunaan antibiotik restriksi bertujuan untuk mengurangi angka kejadian resistensi antibiotik. Antibiotik Restriksi sendiri merupakan Antibiotik yang dibatasi penggunaannya dengan tujuan menekan angka kejadian resistensi antibiotik. Dalam standar operasional antibiotik restriksi digunakan hanya untuk pasien yang telah melakukan uji kultur dan Pemilihan jenis antibiotik restriksi harus sesuai dengan jenis bakteri yang menginfeksi bukan berdasarkan jenis penyakit. Tertuang dalam peraturan menteri kesehatan RI nomor 8 tahun 2015 tentang PPRA di Rumah sakit terdapat kebijakan-kebijakan dalam penggunaan antibiotik yaitu pasien yang secara klinis diduga atau diidentifikasi mengalami infeksi bakteri maka boleh diberikan antibiotik empiris sebelum keluarnya hasil uji kultur dengan ketentuan selama 48-72 jam Akan tetapi kenyataannya yang ada di lapangan menunjukkan penggunaan antibiotik restriksi masih digunakan secara bebas tanpa adanya uji kultur terlebih dahulu, yaitu ada 47 sampel pasien yang diresepkan antibiotik restriksi tanpa adanya uji kultur.

Berdasarkan gambar 2 didapatkan hasil antibiotik restriksi yang digunakan pada pasien rawat inap tahun 2017-2019 dengan diagnosa GEA, ISK dan Demam Tifoid yaitu ciprofloxacin (20\%), levofloxacin (8\%) dan meropenem (1\%). Berdasarkan standa operasional penggunaan antibiotik pada formularium nasional, antibiotik ciprofloxacin dan levofloxacin tidak dugunakan untuk pasien $<18$ tahun, selanjutnya penggunaan antibiotik ciprofloxacin dan levoflocaxin maksimal diberikan selama 10 hari, standar tersebut sesuai dengan pengamatan pada penelitian bahwa pasien tidak ada yang diresepkan lebih daro 10 hari.

Antibiotik meropenem dalam standard operasionalnya hanya untuk infeksi ileh kuman ESBL, pada penelitian ini jenis kuman tidak diketahui sehingga peresepan dianggap belum sesui dengan SOP, peresepan ini dinilai tidak tepat sasaran sehingga meningkatkan resiko resistensi antibiotik. Selanjutnya penggunaan antibiotik meropenem maksimal 7 hari, standard tersebut telah sesuai dengan pengamatan pada penelitian bahwa pasien tidak ada yang diresepkab lebih dari 7 hari.

Penggunaan antibiotik restriksi yang paling banyak digunakan adalah Antibiotik ciprofloxacin, antibiotik tersebut merupakan golongan fluorokuinolon. Fluorokuinolon merupakan suatu antibiotik berspektrum lebar yang digunakan secara luas untuk terapi infeksi saluran kemih, infeksi tifoid, pneumonia,bronchitis kronik, infeksi ureter, dan infeksi lainnya. Mekanisme kerja fluorokuinolon bekerja menghambat enzim DNA girase yang sangat penting untuk replikasi DNA dari bakteri. Obat ini membentuk ikatan kompleks dengan masingmasing enzim ini dan DNA bakteri. Hambatan ini menghasilkan efek sitotoksik dalam sel target. Mekanisme 
Journal of Healthcare Technology and Medicine Vol. 6 No. 2 Oktober 2020

Universitas Ubudiyah Indonesia

e-ISSN : 2615-109X

kerja dari fluorokuinolon termamsuk ciprofloxacin berbeda dengan antibiotik lainnya seperti beta-laktam, makrolida, tetrasuklin atau aminoglikosida. Oleh karena itu, organisme resisten terhadap antibiotik-antibiotik tersebut dapat masih sensitive dengan ciprofloxacin. (Raini, 2016)

\section{KESIMPULAN}

Berdasarkan hasil penelitian yang telah dilakukan dapat disimpulkan bahwa penggunaan antibiotik restriksi di poli penyakit dalam pada penyakit GEA, ISK dan Demam Tifoid di RSUD H. Abdul Manap kota jambi pada periode 2017-2019 yaitu Pada diagnosis GEA mengalami peningkatan dan penetapan yaitu sebesar $22 \%$ 44\%, 44\%. Pada diagnosis ISK mengalami peningkatan dan penurunan, yaitu sebesar 16\%, 43\%, $29 \%$. Pada diagnosis demam tifoid mengalami penurunan dan peninkatan yaitu pada tahun 2017 sebesar 19\%, 12\%, $25 \%$.

\section{DAFTAR PUSTAKA}

Arifin, R., Provinsi, A., \& Fauziah, D. (2015). Pola Resistensi Acinetobacter baumannii yang diisolasi Di Intensive care Unit (ICU) RSUD Arifin Achmad Provinsi Riau Periode 1 Januari hingga 31 Desember 2014. Jom FK, volume 2 N, 1-8.

Astuti. (2010). faktor yang berpengaruh terhadap kejadian demam tifoid pada anak. In skripsi. surabaya: universitas airlangga.

Bryce, A., Costelloe, C., Wootton, M., Butler, C. C., \& Hay, A. D. (2018). Comparison of risk factors for, and prevalence of, antibiotic resistance in contaminating and pathogenic urinary Escherichia coli in children in primary care: Prospective cohort study. Journal of Antimicrobial Chemotherapy, 73(5), 1359-1367. https://doi.org/10.1093/jac/dkx525

Desrini, S. (2015). Resistensi Antibiotik, Akankah Dapat Dikendalikan ? Jurnal Kedokteran Dan Kesehatan Indonesia, 6(4). https://doi.org/10.20885/jkki.vol6.iss4.art1

Erikawati, D., Santosaningsih, D., \& Santoso, S. (2016). Tingginya Prevalensi MRSA pada Isolat Klinik Periode 2010- 2014 di RSUD Dr . Saiful Anwar Malang, Indonesia. Jurnal Kedokteran Brawijaya, 29(2), $149-156$.

Estiningsih, D., Puspitasari, I., \& Nuryastuti, T. (2016). Identifikasi Infeksi Multidrug-Resistant Organisms (MDRO) pada Pasien yang Dirawat di Bangsal Neonatal Intensive Care Unit (NICU) Rumah Sakit. Manajemen Dan Pelayanan Farmasi, 6 no 3, 243-248.

Fauzia, D. (2015). STrategi optimasi penggunaan antibiotik. Jurnal Ilmu Kesehatan, 9(2), 55-65.

Herlina, S., Kasih, A., \& Yanah, M. (2015). FAKTOR YANG MEMPENGARUHI TERJADINYA INFEKSI 
Journal of Healthcare Technology and Medicine Vol. 6 No. 2 Oktober 2020

Universitas Ubudiyah Indonesia

e-ISSN : 2615-109X

SALURAN KEMIH PADA PASIEN DEWASA DI RSUD KOTA BEKASI. Jurnal Keperawatan Eidya Gantari, (2), 100-115.

Hidayanti, R. (2012). Universitas indonesia faktor risiko diare di kecamatan cisarua, cigudeg dan megamendung kabupaten bogor tahun 2012. Skripsi.

Kendari, H. (2018). IDENTIFIKASI DRUG RELATED PROBLEM ( DRP ) PADA PASIEN INFEKSI SALURAN KEMIH. Jurnal Kesehatan, 11(1), 39-50.

Korompis, F., Tjitrosantoso, H., Goenawi, L. R., Studi, P., Fmipa, F., \& Manado, U. (2013). STUDI PENGGUNAAN OBAT PADA PENDERITA DIARE AKUT DI INSTALASI RAWAT INAP BLU RSUP PROF . DR . R . D . KANDOU MANADO PERIODE JANUARI-JUNI 2012. Jurnal Ilmiah Farmasi, 2(01), 42-51.

Melarosa, P. R., Ernawati, D. K., \& Mahendra, A. N. (2019). POLA PENGGUNAAN ANTIBIOTIKA PADA PASIEN DEWASA DENGAN DEMAM TIFOID DI RSUP SANGLAH DENPASAR TAHUN 20162017. E-Jurnal Medika, 8(1), 12-16.

Negara, K. S. (2014). Analisi Implementasi Kebijakan Penggunaan Antibiotika Rasional Untuk Mencegah Resistensi Antibiotika di RSUP Sanglah Denpasar: Studi Kasus Infeksi Methicillin Resistant Staphylococcus Aureus. Jurnal Administrasi Kebijakan Kesehatan, 1, 42-50.

Nuruzzaman, H. dkk. (2016). analisis risiko kejadian demam tifoid berdasarkan kebersihan diri dan kebiasaan jajan di luar dirumah. (July), 74-86. https://doi.org/10.20473/jbe.v4i1.74-86

Nuryah, A., Yuniarti, N., \& Puspitasari, I. (2019). Prevalensi dan Evaluasi Kesesuaian Penggunaan Antibiotik pada Pasien dengan Infeksi Methicillin Resistant Staphylococcus Aureus di RSUP Dr . Soeradji Tirtonegoro Klaten. Jurnal $\quad$ Farmaseutik, $\quad$ 15(2), https://doi.org/10.22146/farmaseutik.v15i2.47911

Pramitasari, O. P. (2013). Faktor Risiko Kejadian Penyakit Demam Tifoid pada Penderita yang Dirawat di Rumah Sakit Umum Daerah Ungaran. Junal Kesehatan Masyarakat, 2, 1-10.

Pratama, S. (2019). Monitoring penggunaan antibiotik di Bangsal Penyakit Dalam RSUD Kerinci. Riset Informasi Kesehatan, 8(1), 57-62. https://doi.org/10.30644/rik.v7i1.225

Raini, M. (2016). Antibiotik Golongan Fluorokuinolon : Manfaat dan Kerugian. 163-174.

Rakhman. (2009). faktor-faktor risiko yang berpengaruh terhadap kejadian demam tifoid pada orang dewasa. In tesis. yogyakarta: universitas gajah mada.

Savitri, F., Pratistha, M., Sudhana, I. W., \& Adnyana, I. W. L. (2017). Diagnosis cepat infeksi saluran kemih dengan menghitung jumlah leukosituria pada urinalisis metode flowcytometry sysmex ux-2000 dengan baku emas kultur urin di RSUP Sanglah Denpasar. Jurnal Penyakit Dalam Udayana, 1 no 2, 52-56. 
Journal of Healthcare Technology and Medicine Vol. 6 No. 2 Oktober 2020

Universitas Ubudiyah Indonesia

e-ISSN : 2615-109X

Sjahjadi, novilla rezka, Rasyid, R., Rustam, E., \& Restusari, L. (2014). Prevalensi Kuman Multi Drug Resistance ( MDR ) di Laboratorium Mikrobiologi RSUP Dr . M . Djamil Padang Periode Januari 2010 Desember 2012. Jurnal Kesehatan Andalas, 3(3), 440-444.

Utami, E. R. (2011). Antibiotika, resistensi, dan rasionalitas terapi. Jurnal Antibiotik, 1(4), 191-198. 
Journal of Healthcare Technology and Medicine Vol. 6 No. 2 Oktober 2020

Universitas Ubudiyah Indonesia

e-ISSN : 2615-109X 